\title{
Outcome of Both Bone Forearm Fracture Fixation in Children by Rush Nails
}

\author{
Rajeev Dwivedi, ${ }^{2}$ Ruban Joshi, ${ }^{1}$ Sagar Panthi, ${ }^{1}$ Subin Byanjankar, ${ }^{1}$ Rahul Shrestha' \\ 'Department of Orthopaedics, Lumbini Medical College and Teaching Hospital, Tansen, Palpa, Nepal.
}

Introduction: Forearm fractures are common upper limb injuries among children and usually treated non-operatively. Failure of non-operative treatment, open injuries and multiple fractures are the indications for surgery in paediatric both bone forearm fractures. Intramedullary nailing is considered as minimally invasive procedure with excellent to fair outcomes but it is not free of complications. We reviewed the results and evaluated the outcomes of IM fixation of forearm fractures in children by Rush nails to understand the risks and complications associated with these procedures.
\end{abstract}

Methods: A retrospective crossectional study of all paediatric patients treated for diaphyseal forearm fractures for period of five years in a tertiary care setup. Complications were classified according to modified Clavien-Dindo complication classification system. Outcomes were graded depending upon complication grade along with range of motion of forearm.

Results: A total of 25 patients were included in the study. Mean time for fracture union was 10.56 weeks. Outcomes were excellent in $16(64 \%)$, good in $7(28 \%)$, fair in $2(8 \%)$ patients and no poor outcome was noted. Ten minor complications were seen.

Conclusion: Fixation of paediatric forearm fractures by intramedullary Rush nail is minimally invasive procedure and outcomes are excellent to fair with acceptable complication rates.

Keywords: complication; forearm fractures; intramedullary nailing; outcome; paediatrics; Rush nail.

\section{INTRODUCTION}

Diaphyseal forearm fractures are common upper limb injuries among children. Non-operative treatment in the form of close reduction and cast application is the standard method for treating most of these fractures, as most of the children with displaced forearm fractures achieve satisfactory results with this treatment. ${ }^{1}$ Operative treatment of paediatric forearm fractures is indicated for patients in whom satisfactory alignment cannot be achieved by close reduction and cast application, in multiple bone fractures and in compound fractures. Results of nonoperative treatment of paediatric diaphyseal forearm fractures are favourable in the majority of cases, despite of that surgical treatment for such injuries are increasing nowadays. A study showed an increase in the rate of surgical treatment of paediatric forearm fractures in the form of intramedullary (IM) nailing from $1.8 \%$ to $22 \%$ over

Correspondence: Dr. Rajeev Dwivedi, Department of Orthopaedics, Lumbini Medical College and Teaching Hospital, Palpa, Nepal. E-mail: rd172002@gmail.com, Phone: +977-9851091933. 
a 10-year period. ${ }^{2}$ Increasing trend towards operative treatment of paediatric forearm fractures may be due to technologic advances and its accessibility, awareness of parents, and liability concerns of surgeons and may be due to medical economics.

Various types of implants can be used for IM fixation of forearm fracture like k-wires, Rush nails and titanium elastic nails. Several studies have shown excellent to good results of IM nailing of paediatric forearm fractures, leading to increase in practice of IM fixation of such injuries. ${ }^{3,4}$ There are several minor and major complications associated with IM Fixation including delayed union, nonunion, need to frequently expose the fracture site, compartment syndrome (CS), and wound problems. $^{4}$

The purpose of this study was to review the results and evaluate the outcomes of IM fixation of paediatric forearm fractures by Rush nails, to better understand the risks and complications associated with these procedures.

\section{METHODS}

This retrospective study was conducted in the Department of Orthopaedics, Lumbini Medical College and Teaching Hospital, Palpa, Nepal after approval from the Institutional review board. We performed a retrospective review of all paediatric patients treated for diaphyseal forearm fractures between January 2011 to December 2015. We collected data entered in computer, reviewed the clinic notes, operative summaries, and radiographic films for this selected group of patients to get the following information: age and gender of patients, date of injury, date of surgery, fracture location, injured limb, indications for surgery, type of implant used, duration of follow-up, time to radiographic union, final range of forearm motion, and postoperative complications. Any patient with a pathologic fracture, radial head fracture, Monteggia or Galeazzi fractures, isolated single bone fracture and compound (open) fractures were not included in this study. Both bone fractures where single bone fixation was done, fractures those were fixed with other type of implants like k-wires; titanium elastic nails were also excluded from study. Fracture union beyond 3 months was defined as a "delayed union" and failure of fracture union beyond 6 months was defined as a "nonunion. ${ }^{5}$ Clinical outcomes were graded from the records available at final follow up according to classification system proposed by Jeffrey E. Martus et al. ${ }^{6}$ This classification system include range of motion (ROM) of forearm and post operative surgical complications classified according to the Clavien-Dindo complication classification system as shown in table $1 .^{7}$ Normal forearm rotation was considered to be 70 degrees of pronation and 85 degrees of supination. An outcome was judged excellent if the forearm rotation was normal (full) and no complications greater than grade 1 occurred.

\begin{tabular}{|c|c|c|}
\hline $\begin{array}{l}\text { Complication } \\
\text { grade }\end{array}$ & Definition & Examples \\
\hline 1 & $\begin{array}{l}\text { Deviation from } \\
\text { a routine } \\
\text { postoperative } \\
\text { course } \\
\text { without the } \\
\text { need for } \\
\text { intervention }\end{array}$ & $\begin{array}{l}\text { Asymptomatic } \\
\text { delayed union } \\
\text { Prominent implant }\end{array}$ \\
\hline 2 & $\begin{array}{l}\text { Resolution after } \\
\text { outpatient } \\
\text { management, } \\
\text { pharmacologic } \\
\text { therapy, } \\
\text { or close } \\
\text { observation }\end{array}$ & $\begin{array}{l}\text { Superficial infection } \\
\text { Transient nerve } \\
\text { palsy }\end{array}$ \\
\hline 3 & $\begin{array}{l}\text { Requiring } \\
\text { inpatient } \\
\text { management or } \\
\text { reoperation }\end{array}$ & $\begin{array}{l}\text { Deep infection } \\
\text { Implant migration } \\
\text { requiring early } \\
\text { Removal }\end{array}$ \\
\hline 4 & $\begin{array}{l}\text { Complication } \\
\text { that is limb } \\
\text { threatening, life } \\
\text { threatening, } \\
\text { or resulting in } \\
\text { a permanent } \\
\text { deficit }\end{array}$ & $\begin{array}{l}\text { Compartment } \\
\text { syndrome } \\
\text { Permanent nerve } \\
\text { palsy } \\
\text { Radioulnar } \\
\text { synostosis } \\
\text { Tendon rupture }\end{array}$ \\
\hline 5 & $\begin{array}{l}\text { Death of } \\
\text { patient }\end{array}$ & $\begin{array}{l}\text { Postoperative } \\
\text { mortality } \\
\text { secondary to } \\
\text { anesthetic reaction }\end{array}$ \\
\hline
\end{tabular}

\begin{tabular}{|c|c|c|}
\hline Outcome grade & Range of Motion & $\begin{array}{l}\text { Complication } \\
\text { Grade }\end{array}$ \\
\hline Excellent & Full & $\begin{array}{l}\text { Grade } 1 \text { or } \\
\text { none }\end{array}$ \\
\hline Good & $\begin{array}{l}\text { Loss of }<10 \\
\text { degrees pronation } \\
\text { and/or supination }\end{array}$ & $\begin{array}{l}\text { Grade } 2 \text { or } \\
\text { less }\end{array}$ \\
\hline Fair & $\begin{array}{l}\text { Loss of } 10-30 \\
\text { degrees pronation } \\
\text { and/or supination }\end{array}$ & $\begin{array}{l}\text { Grade } 3 \text { or } \\
\text { less }\end{array}$ \\
\hline Poor & $\begin{array}{l}\text { Loss of }>30 \\
\text { degrees pronation } \\
\text { and/or supination }\end{array}$ & Up to grade 5 \\
\hline
\end{tabular}


A good result was based upon mild loss of forearm rotation ( $<10$ degrees) with complications up to grade 2. A fair result was reported if loss of rotation was more significant (10 to 30 degrees) and complications were grade 3 or less in severity. A poor result was given if there was a significant loss of rotation ( $>30$ degrees) and/ or there were complications of grade 4 or 5 in severity as shown in Table 2.

\section{RESULTS}

Twenty five patients, 15 males and 10 females met the inclusion criteria. Mean age was 10.31 years (range, $5-15$ years). Fifteen patients $(60 \%)$ of them got fractured due to fall while playing.Indication for surgery was unacceptable reduction following close reduction and cast application in 15 (60\%) patients, floating elbow in 1 (4\%) patient and in $9(36 \%)$ patients surgery was selected as a primary method of treatment. Side involved, location of fracture and type of reduction are shown in table 3 .

\begin{tabular}{|llc|}
\hline Table 3. Fracture pattern and type of reduction. \\
\hline Forearm & Right & 15 \\
Fractured & Left & 10 \\
& Proximal third & 4 \\
Fracture & Middle third & 16 \\
location & Distal third & 5 \\
$\begin{array}{l}\text { Mini Open } \\
\text { reduction } \\
\text { required }\end{array}$ & Radius & $2(8 \%)$ \\
& $\begin{array}{l}\text { Radius and } \\
\text { ulna both }\end{array}$ & $3(16 \%)$ \\
\hline
\end{tabular}

The average time interval from injury to surgery was 2.4 days (range, 2 to 6 days). Reduction of fracture was achieved in 16 (64\%) patients by closed method and 9 $(36 \%)$ patients (radius in $2(8 \%)$, ulna in $4(16 \%)$ and radius and ulna both in $3(12 \%)$ patients) required open reduction. Patients were immobilized postoperatively in long arm cast or in above elbow posterior slab with an average duration of 4.88 weeks ( 4 to 8 weeks) .

Mean time to fracture union was (10.56 weeks; range, 6 to 16 weeks). Out of 25 patients 20 (80\%) patients had normal forearm rotation and normal flexion and extension of elbow and wrist.

Loss of forearm rotation less than 30 degree was noted in $5(20 \%)$ patients. As per classification system proposed by Jeffrey E. Martus et al. ${ }^{6}$ outcomes were excellent in $16(64 \%)$, good in $7(28 \%)$, fair in $2(8 \%)$ patients and no poor outcome was noted.

Postoperative complications occurred in 10 (40\%) patient. Out of 10 complications 6 were asymptomatic delayed union that united without intervention within the 16 weeks. Remaining 4 complications were grade 2. One patient developed superficial radial nerve palsy, which resolved spontaneously without treatment. One had superficial wound infection that resolved with oral antibiotics and dressing. Two patients developed a pin site irritation one on radial and one on ulnar site that resolved after implant removal.

\begin{tabular}{|c|c|}
\hline & $\begin{array}{l}\text { Total } \\
\text { cases (25) }\end{array}$ \\
\hline $\begin{array}{l}\text { Grade } 1 \text { complications } \\
\text { Asymptomatic delayed union }\end{array}$ & 6 \\
\hline $\begin{array}{l}\text { Grade } 2 \text { complications } \\
\text { Superficial infection }\end{array}$ & 1 \\
\hline Postoperative neuropraxia (transient) & 1 \\
\hline Symptomatic Prominent implant & 2 \\
\hline Grade 3 complications & 0 \\
\hline Grade 4 complications & 0 \\
\hline Grade 5 complications & 0 \\
\hline Overall complications & 10 \\
\hline ROM & \\
\hline 1. Full & \\
\hline $\begin{array}{l}\text { 2. Loss of }<10 \text { degrees } \\
\text { pronation and/or supination }\end{array}$ & 3 \\
\hline $\begin{array}{l}\text { 3. Loss of } 10-30 \text { degrees } \\
\text { pronation and/or supination }\end{array}$ & 2 \\
\hline $\begin{array}{l}\text { 4. Loss of }>30 \text { degrees } \\
\text { pronation and/or supination }\end{array}$ & 0 \\
\hline $\begin{array}{l}\text { Outcomes } \\
\text { Excellent }\end{array}$ & 16 \\
\hline Good & 7 \\
\hline Fair & 2 \\
\hline Poor & 0 \\
\hline
\end{tabular}

Latest follow up available was 28.72 weeks (16 to 54 weeks) and only 12 (48 \%) patients followed for implant removal. Indication of implant removal was solid union in all cases with complete obliteration of fracture line. Mean time at which implant was removed was 30.66 (16 to 52 ) weeks from the time of index surgery. 
Dwivedi et al. Outcome of Both Bone Forearm Fracture Fixation in Children by Rush Nails

\begin{tabular}{|c|c|c|c|c|c|c|c|c|c|}
\hline & $\begin{array}{l}\text { Study } \\
\text { period } \\
\text { Years }\end{array}$ & $\begin{array}{l}\text { Total } \\
\text { patients } \\
\text { (n) }\end{array}$ & Sex & $\begin{array}{l}\text { Mean } \\
\text { age }\end{array}$ & $\begin{array}{l}\text { Type of } \\
\text { implant used }\end{array}$ & $\begin{array}{l}\text { Average time } \\
\text { to radiological } \\
\text { union }\end{array}$ & $\begin{array}{l}\text { Functional } \\
\text { outcome } \\
\text { assessment } \\
\text { Criteria }\end{array}$ & $\begin{array}{l}\text { Functional } \\
\text { outcome }\end{array}$ & Complications \\
\hline $\begin{array}{l}\text { Flynn JM } \\
\text { et al } 3\end{array}$ & $11 \mathrm{yrs}$ & 103 & $\begin{array}{l}\text { Not men- } \\
\text { tioned }\end{array}$ & 10.6 & $\begin{array}{l}\text { Tita- } \\
\text { nium nails, } \\
\text { Kirschner } \\
\text { wire }\end{array}$ & $\begin{array}{l}6.9-8.6 \\
\text { weeks }\end{array}$ & $\begin{array}{l}\text { Children hospital } \\
\text { of Pheladelphia } \\
\text { forearm fracture } \\
\text { fixation outcome } \\
\text { classification }\end{array}$ & $\begin{array}{l}\text { Excellent }= \\
77.7 \% \\
\text { Fair }=14.6 \% \\
\text { Poor }=7.8 \%\end{array}$ & $\begin{array}{l}\text { Major }=4(3.8 \%) \\
\text { Minor }=11(10.6 \%)\end{array}$ \\
\hline $\begin{array}{l}\text { Richter D } \\
\text { et al } 13\end{array}$ & $2 \mathrm{yrs}$ & 30 & $\begin{array}{l}M=18 \\
F=12\end{array}$ & $\begin{array}{l}\text { Not men- } \\
\text { tioned }\end{array}$ & $\begin{array}{l}\text { Titanium } \\
\text { Nails }\end{array}$ & 13 weeks & Tscherne score & $\begin{array}{l}\text { Excellent }= \\
80 \% \\
\text { Good }= \\
16.6 \% \\
\text { Fair }=3.3 \%\end{array}$ & Minor $=4(13.3 \%)$ \\
\hline $\begin{array}{l}\text { Shoemaker } \\
\text { SD et al } \\
14\end{array}$ & $8 \mathrm{yrs}$ & 32 & $\begin{array}{l}M=22 \\
F=10\end{array}$ & 8.8 & $\begin{array}{l}\text { Kirschner } \\
\text { wire }\end{array}$ & 12 weeks & Price criteria & $\begin{array}{l}\text { Excellent }= \\
96.8 \% \\
\text { Good }=3.2 \%\end{array}$ & $\begin{array}{l}\text { Major }=2(6.2 \%) \\
\text { Minor }=7(21.8 \%)\end{array}$ \\
\hline $\begin{array}{l}\text { Yalcinkaya } \\
\text { M et. al } \\
15\end{array}$ & $8 \mathrm{yrs}$ & 45 & $\begin{array}{l}M=35 \\
F=10\end{array}$ & 10 & $\begin{array}{l}\text { Rush pins, } \\
\text { Kirschner } \\
\text { wire }\end{array}$ & $6-10$ weeks & Price criteria & $\begin{array}{l}\text { Excellent }= \\
82.2 \% \\
\text { Good }= \\
17.8 \%\end{array}$ & $\begin{array}{l}\text { Major }=2(4.44 \%) \\
\text { Minor }=15(33.3 \%)\end{array}$ \\
\hline $\begin{array}{l}\text { S.-N. Kang } \\
\text { et al } 16\end{array}$ & $10 y r s$ & 90 & & $\begin{array}{l}8.4(2- \\
15)\end{array}$ & Elastic nails & $\begin{array}{l}2.9 \text { months } \\
\text { (1.1 to } 8.7)\end{array}$ & $\begin{array}{l}\text { Daruwalla cri- } \\
\text { teria }\end{array}$ & $\begin{array}{l}\text { Excellent } 59 \\
\text { Good } 17 \\
\text { Fair } 5 \\
\text { Poor } 9\end{array}$ & $\begin{array}{l}\text { Superficial radial } \\
\text { nerve palsy } 2 \\
\text { Compartment } \\
\text { syndrome } \\
\text { Delayed union } 1 \\
\text { Malunion } 1 \\
\text { Remodelled } \\
\text { Wound-related } \\
\text { problems } 7 \\
\text { Failure to remove } \\
\text { implant } 1\end{array}$ \\
\hline $\begin{array}{l}\text { Parajuli NP } \\
\text { et al } 17\end{array}$ & $3 \mathrm{yrs}$ & 50 & $\begin{array}{l}M=38 \\
F=12\end{array}$ & 10.4 & Rush pins & 8 weeks & Price criteria & $\begin{array}{l}\text { Excellent }= \\
94 \% \\
\text { Good }=6 \%\end{array}$ & Minor $=8(16 \%)$ \\
\hline $\begin{array}{l}\text { Jeffrey E. } \\
\text { Martus et } \\
\text { al } 6\end{array}$ & $11 \mathrm{yrs}$ & 203 & $\begin{array}{l}\text { Male } \\
=65 \% \\
\text { Female } \\
=35 \%\end{array}$ & 9.7 & $\begin{array}{l}\text { TENs } 97 \% \\
3 \% \mathrm{k}=\text { wires } \\
\text { or Steinman } \\
\text { pins }\end{array}$ & Not available & $\begin{array}{l}\text { Clavien-Dindo } \\
\text { classification } \\
\text { with modifica- } \\
\text { tions }\end{array}$ & $\begin{array}{l}\text { Excellent } 163 \\
\text { Good } 24 \\
\text { Fair } 5 \\
\text { Poor } 13\end{array}$ & $\begin{array}{l}\text { Overall complication } \\
21 \% \\
17 \% \text { were grade } 2 \\
\text { or greater }\end{array}$ \\
\hline Our study & $5 y r s$ & 25 & $\begin{array}{l}M=15 \\
F=10\end{array}$ & 10.31 & Rush nails & $\begin{array}{l}\text { Rush nails } \\
10.56 \text { wks }\end{array}$ & $\begin{array}{l}\text { New } \\
\text { classification as } \\
\text { used by Jeffrey } \\
\text { E. Martus et al }\end{array}$ & $\begin{array}{l}\text { Excellent } 16 \\
\text { Good } 7 \\
\text { Fair } 2 \\
\text { Poor } 0\end{array}$ & $\begin{array}{l}10 \text { Minor } \\
\text { complicatios }\end{array}$ \\
\hline
\end{tabular}

\section{DISCUSSION}

Diaphyseal forearm fractures are common fractures among children. Closed reduction and cast immobilization is the standard method of treatment for most of these fractures. ${ }^{1}$ Malreduction can lead to restriction in forearm rotation and function. There is variable opinion regarding acceptable degree of angulation and acceptable range of forearm rotation. A study by Daruwalla ${ }^{8}$ followed the long-term clinical outcomes 
of 53 forearm fractures treated with closed reduction and cast immobilization. He found that although 28 patients demonstrated notable limitations of supination, pronation, or both upon clinical examination, none of these patients complained of difficulties related to forearm motion. Morrey et al ${ }^{9}$ determined that the majority of daily activities can be performed with 100 degree of forearm rotation equally divided between pronation and supination. These two studies suggest that the residual angulation after nonoperative treatment may be well tolerated by children.

Several other investigators found that fracture angulation between 5 to 10 degrees at the level of mid-shaft of the forearm can lead to pronation deficits of $10 \%$ to $83 \%$ of normal and supination deficits of $5 \%$ to $27 \%$ of normal. ${ }^{10}$ Remodeling capacity of bone decreases with increasing age. Study has shown children ten years or older do not predictably remodel to a significant degree. ${ }^{11}$ Incidence of poor results of closed treatment of fractures in children older than ten years old remains widely under reported. ${ }^{12}$ Considering this functional limitation due to malreduction of fracture and unpredictable remodeling capacity in older children there is increase in trend towards operative treatment of pediatric forearm fractures. There are situations, however, in which operative management is beneficial to avoid repeated reductions, additional corrective surgical procedures, and functional limitations. Plating is considered as standard method of fixation in adults whereas intramedullary nailing by Rush Nails, TENs or $\mathrm{K}$ wires are considered as standard methods of fixation of forearm fractures in children.

Various studies have shown that IM nailing can provide precise fracture reduction, maintain the reduction for fracture healing, results in minimal cosmetic deformity, and facilitates easy removal of implants after treatment. ${ }^{3}$,

4 However; IM nailing is not free of complications. Documented complications of this technique include infections at nail insertion site, skin irritation at nail insertion sites, fracture displacement after implant removal, migration or failure of implants (bent or broken nails), loss of reduction, refracture, nerve and tendon injury, decreased range of motion, delayed union and nonunion, and compartment syndrome(CS). ${ }^{3,4}$

In our study mean age of patients was 10.31 years similar to previous other studies and this is the age around which fixation is required for better radiological and functional outcome due to decreasing remodeling capacity. Reduction of fracture was achieved in 16 $(64 \%)$ patients by closed method and in 9 (36\%) patients open reduction was required. The frequency of open reduction during IM fixation in previously closed fractures has been reported to be as high as $38 \%$ to $74.4 \%$ in the literature. ${ }^{13-16}$. We have not compared the outcome of closed with open nailing in our study. Merter Yalcinkaya et al ${ }^{15}$ concluded closed reduction or open reduction with a mini incision for intramedullary nailing yield similar functional results, with a similar complications rate in the treatment of pediatric unstable diaphyseal forearm fractures.

In this study post operative complications were evaluated with the modified Clavien-Dindo classification system. This classification sysytem provides uniformity in the reporting of complications because this system uses objective criteria for the severity scale. An advantage of this classification is the elimination of the potential subjective bias that is associated with the grouping of complications in grades as minor/major or mild/moderate/severe. ${ }^{7}$

Outcomes and complications in the present study are comparable to other various studies as shown in (table no 5). ${ }^{3,4,13-17}$ Yalcinkaya $\mathrm{M}$ et $\mathrm{al}^{15}$ reporetd complications rate range from $4-38 \%$ in patients treated with intramedullary nailing and results were excellent in $82.2 \%$ and good in $17.8 \%$ of patients. Flynn JM et al 3 reported $77.7 \%$ excellent, $14.6 \%$ fair and $7.8 \%$ poor results and showed that the overall complication rate in patients undergoing intramedullary nailing was $14.6 \%$. $^{3}$ The most common complication occurring in their series were infection, skin irritation by hard ware, pin back out, delayed union and compartment syndrome.

In our series, 10 minor complications were noted. Among which 6 were asymptomatic delayed union. We considered delayed union as minor complication which united without any interventions. No nonunion or malunion occurred in our series. There were no deep infections noted. Flynn noted compartment syndrome (CS) in those patients those were operated within first 24 hours. However, in our study no case was operated in first 24 hours, which may be the reason of not getting any complication in the form of CS in our study. Parajuli NP et al reported excellent outcomes in $94 \%$ and good in $6 \%$ of patients. There were only $8(16 \%)$ minor complications . ${ }^{14}$

\section{CONCLUSIONS}

Intramedullary fixation of forearm fractures in children by Rush nail is minimally invasive procedure and outcomes are excellent to fair with acceptable poor results. Overall outcomes in this study are comparable to various other studies, with reasonable complication rate. Since Rush nails are easily available and affordable in developing countries like ours, we can prefer Rush nails for intramedullary fixation of paediatric forearm fractures. Retrospective and non comparative nature were limitations of this study. 


\section{REFERENCES}

1. Rodríguez-Merchán EC. Pediatric fractures of the forearm. Clin Orthop 2005;432:65-72.

2. Schmittenbecher PP. State-of-the-art treatment of forearm shaft fractures. Injury. 2005;36:S-A25-S-A34.

3. Flynn J, Jones K, Garner M, Goebel J. Eleven years experience in the operative management of pediatric forearm fractures. J Pediatr Orthop 2010;30:313-9

4. Akash Patel, Lily Li, Amarjit Anand. Systematic review: Functional outcomes and complications of intramedullary nailing versus plate fixation for both-bone diaphyseal forearm fractures in children. Injury, Int. J. Care Injured 2014; 45:1135-1143

5. Schmittenbecher PP, Peter P, Fitze G, et al. Delayed healing of forearm shaft fractures in children after intramedullary nailing. J Pediatr Orthop.2008;28:303-306.

6. Jeffrey E. Martus, Ryan K. Preston, Jonathan G. Schoenecker et al Complications and Outcomes of Diaphyseal Forearm Fracture Intramedullary Nailing: A Comparison of Pediatric and Adolescent Age Groups J Pediatr Orthop Volume 33, Number 6, September 2013;33:598-607

7. Clavien P, Barkun J, de Oliveira ML, et al. The Clavien-Dindo Classification of surgical complications.Ann Surg. 2009;250:187-196

8. Daruwalla JS. A study of radioulnar movements following fractures of the forearm in children. Clin Orthop. 1979;139:114-120.

9. Morrey B, Askew L, An K, et al. A biomechanical study of normal functional elbow motion. J Bone Joint Surg [Am]. 1981;63:872-877
10. Dumont $\mathrm{CE}^{1}$, Thalmann R, Macy JC The effect of rotational malunion of the radius and the ulna on supination and pronation. J Bone Joint Surg Br. 2002 Sep; 84(7):1070-4.

11. Vittas D, Larsen E, Torp-Pedersen S. Angular remodeling of midshaft forearm fractures in children. Clin Orthop. 1991:261-264.

12. Kay S, Smith C, Oppenheim WL. Both-bone midshaft forearm fractures in children. J Pediatr Orthop. 1986;6:306-310

13. Richter D, Ostermann P, Ekkernkamp A, Muhr G, Hahn MP. Elastic intramedullary nailing: a minimally invasive concept in the treatment of unstable forearm fractures in children. J Pediatr Orthop 1998; 18:457-61

14. Shoemaker S. Comstock C. Mubarak S, Wenger DR, Chambers HG. Intramedullary Kirschner wire fixation of open or unstable forearm fractures in children. J Pediatr Orthop1999; 19:329-37

15. Yalcinkaya M, Dogan A, Ozkaya V, Sokucu S, Uzumcugil O, Kabukcuoglu Y. Clinical results of intramedullary nailing following closed or mini open reduction in pediatric unstable diaphyseal forearm fractures. Acta Orthop Traumatol Turc2010; 44 (1): 7-13.

16. S.-N. Kang, J. Mangwani, M. Ramachandran, J. M. H. Paterson, M. Barry. Elastic intramedullary nailing of paediatric fractures of the forearm. A decade of experience in a teaching hospital in the united kingdom.J Bone Joint Surg [Br] 2011;93-B:262-5

17. Parajuli NP, Shrestha D, Dhoju D, Dhakal GR, Shrestha $\mathrm{R}$, Sharma V. Intramedullary nailing for paediatric diaphyseal forearm bone fracture. Kathmandu Univ Med J. 2011;35(3):198-202 